This is a post-peer-review pre-print version of an article published in Journal of Romance Studies. The definitive publisher-authenticated version of "Williams, M.T. (2004) Plein soleil and The Talented Mr Ripley: sun, stars and Highsmith's queer periphery. Journal of Romance Studies, 4, (1), 47-62" is available online at:

http://www.ingentaconnect.com/content/berghahn/romance

\title{
Plein soleil and The Talented Mr Ripley: sun, stars and Highsmith's queer periphery
}

\section{Michael Williams}

\begin{abstract}
This article explores two cinematic adaptations of Patricia Highsmith's 1955 novel, The Talented Mr Ripley, about a young anti-hero who murders, and then steals the identity of, another American living in Italy: René Clément's Plein soleil (France/Italy 1960) and Anthony Minghella's The Talented Mr Ripley (US/UK 1999). Drawing on both textual analysis and critical reception, the article explores how the traces of what might be termed Highsmith's 'queer periphery' are manifested and eroticized on the screen. Through such sun-drenched (homo)erotics, there is a very present sense of mythology, queer or otherwise, in the seductive Mediterranean landscape of these texts. The discussion thus explores issues of narrative, the stars Alain Delon, Jude Law and Matt Damon, and sexuality and landscape.
\end{abstract}

Keywords: Patricia Highsmith; Alain Delon; Matt Damon; Jude Law; René Clément; Anthony Minghella; stars; queer

This article focuses on two cinematic adaptations of Patricia Highsmith's 1955 novel The Talented Mr Ripley. ${ }^{1}$ The first, René Clément's 1960 French/Italian production Plein soleil, features a young Alain Delon as the eponymous Tom Ripley, while in Anthony Minghella's 1999 Anglo-American The Talented Mr Ripley (henceforth TMR), Hollywood pin-up Matt 
Damon takes the lead, with an Apolline Jude Law as the unfortunate object of his desire, Richard 'Dickie' Greenleaf. Highsmith's story elaborates the amoral maze constructed by Ripley as we find him sent from New York to Italy's Amalfi Coast by Dickie's wealthy father to persuade his son to return to America. However, Ripley becomes obsessed with the handsome Dickie to the degree that he eventually murders him and assumes his identity, precipitating a series of occasionally deadly deceptions.

Given that the queerness of Highsmith's text has unravelled with increasing explicitness between the mid 1950s and late 1990s, this paper will explore how the implicit traces of what might be termed Highsmith's 'queer periphery' have been transposed into the two films. Such sun-drenched (homo)erotics seem far removed from the oblique way Highsmith approaches her characters in the novels, often through an obscuring fog of mundane, procedural detail. Indeed, there is a very present sense of mythology, queer or otherwise, in the seductive Mediterranean landscape of these texts, as if there were a residual classical iconography that manifests what is often only a structuring absence in Highsmith, particularly in the four novels that followed. ${ }^{2}$ While I shall adopt a position of queer retrospection in looking back at these texts, using textual analysis to elucidate variations and idiosyncrasies in the films' reworking of Highsmith, I will attempt to contextualize them through an exploration of the critical reception of the films upon their original and any subsequent release. In privileging vicissitudes between the prominence of homo- and heterosexual elements of Highsmith's narrative, I do not intend to elaborate a 'true' queer reading of Ripley and the films. On the contrary, any queerness (in all senses) is contingent on the very shifts and inconsistencies with which the texts are modulated, interpreted ('remade') by readers and film-makers alike. Even the term 'queer' is etymologically complex; certainly addressing sexuality by the time of Highsmith's writing, but also possessing felicitous connotations of the twisted, sinister and uncertain. 
In sympathy with its elusive protagonist, the Ripley oeuvre is characterized by deception, metamorphosis and appropriation to the degree that the notion of authenticity and faithfulness, in both literature and film, become highly problematic. It is thus difficult to term Minghella's film a remake of Clément's when they each make very different interpretations of the 'source' text, especially as Highsmith's novels themselves are no strangers to narrative jumps, ellipses and inconsistencies. ${ }^{3}$ However, as I will indicate, the 1999 film does draw on episodes in the earlier one, and both film-makers are keen to exploit the cinematic possibilities of the tale rather than be slavishly faithful to a novel which Minghella considered to be lacking in 'dramatic structure' (James 2000: 16). Indeed, most Highsmith adaptations, including Hitchcock's version of her Strangers on a Train (1951), are perhaps denoted if anything by a sense of concerted and promiscuous and deviating unfaithfulness, as if in sympathy with their protagonists.

Indeed, the press of 1961 seemed unsure about Clément's ability to adapt Highsmith for the screen. 'A French Hitchcock' was needed, thought The Times, and many concurred (Times 1961). ${ }^{4}$ Also, while critics in the 1990s almost drool over the murderously chic Delon as I will discuss shortly, the press of the 1960s was more uncertain, as if Ripley constituted a new, post-noir presence on the screen. As Derick Hill wrote, Delon 'leaves the murderer an unknown and unknowable figure', not helped, he suggests, by the 'attempts of a French cast to play American characters' (Hill 1961). The Monthly Film Bulletin agreed that there was a literal problem in translation (American colloquialisms pervade the dialogue and English names are retained, with the exception of Dickie, who becomes 'Philippe'), feeling that the 'French passion for things American' had resulted in a 'confusion of nationalities' as well as a collision of New Wave and traditional aesthetics (P.H. 1961: 95) ${ }^{5}$ Indeed, as Chris Darke has pointed out, the film marks Clément's attempt to break away from the disdained tradition of le cinéma de papa and, using Truffaut's cinematographer Henri Decaë and Chabrol's script collaborator Paul Gégauff, move towards the New Wave with rising star Delon, though it 
remained a glossy literary adaptation filmed in Eastmancolor (Darke 1997). The film's sense of linguistic and geographical indeterminacy, I would argue, suits both the fundamental ambiguity of the Ripley character and the theme of travel and reinvention that runs through the text. After all, the film concerns Americans abroad, figures Highsmith acidly critiques in the novels - herself an American émigré who lived in France, Switzerland and Britain from the 1950s and whose work proved more successful in Europe than America (Walter 2003: 13) - and the question of whether identity is formed by birth, culture or can be wilfully shaped as Minghella's Ripley hopes, thinking it better to be a 'fake somebody than a real nobody'.

Clément and Minghella have received some criticism for their handling of their films' closure, and more specifically for having to condemn their anti-hero for his sexual and social deviation. Plein soleil does this most explicitly, with Philippe's body turning up as damning evidence just at the moment when Ripley's heterosexuality has been apparently secured through his relationship to the dead man's ex-girlfriend, Marge (Marie Laforêt). An effective and ironic dénouement, certainly, but one that closes rather than raises moral or sexual ambiguity. TMR has also been critiqued for 'imprisoning' Ripley in his own mind as he sits alone in a ship's cabin at the end of the film, Sight and Sound suggesting that Minghella revealed a 'conservatism' avoided by Highsmith who frees Ripley to sail to Greece at the end of the novel (O'Sullivan 2000: 54). While Highsmith's Ripley is evidently psychologically troubled, the narrator describing the 'nameless, formless things that haunted his brain like Furies', Minghella's film, by bringing such nameless things much more powerfully to visibility, finds that it then has to deal with them (Highsmith 1999a: 186). In making Ripley more overtly homosexual - most notably through a new gay character, Peter Smith-Kingsley (Jack (Jack Davenport), who becomes Ripley's unfortunate partner in the final reel - it could be argued that $T M R$ becomes a more closed if not closeted text, defining and, to some extent, limiting the queerness of its protagonist. I would not go so far, but ambiguity is surely the byword of the Highsmith oeuvre, a narrative world where 'the false, the fake and the 
counterfeit always triumph over the true, the real and the authentic' (Wilson 2003: 295). It is also the incorporeal, fluid, nature of the Ripley books, I suggest, that makes them particularly conducive to remaking and remoulding to fit the shape of shifting fashions, mores and sensibilities across the decades.

\section{The queer periphery}

Homosexuality is pronounced more equivocally in Plein soleil, and Hollis Alpert was one of the few writers who acknowledged the 'plainly homosexual overtones' of the film at the time of its release. However he also recognized that 'just what it is all supposed to mean is kept carefully vague by the dialogue and Clément's arty camera' (Alpert 1961). From the late 1990s viewpoint, the film appeared even more surreptitious about these 'overtones'; the Gay Times noting, for example, the 'unacknowledged' (though nonetheless apparent) sexual frisson between the men, while the Evening Standard considered the film to have been 'damaged by being relentlessly beautiful', thus despite this 'gloss', the film grips 'because of what it hints at, rather than what it exploits' (Stimpson 1997: 93; Walker 1997: 17). Such mincing around the issue would no doubt have pleased Highsmith who, aside from the novel Carol, published under a pseudonym, avoided directly articulating her own sexuality (though one could rightly question why she should) in her work. She chose instead, as Natasha Walter observes, to 'transmute her own homosexuality into a more oblique homoeroticism' such as that of Ripley's obsession with Dickie (Walter 2003: 13).

Highsmith is a figure of almost as many contradictions as Ripley, a woman who loved women but could also be misogynistic, perhaps reflected in her marginalization of women in the Ripley books - Tom's wife Heloise is regularly exiled for long weekends in order for something interesting to happen, for example - something which the films strive hard to overcome. Hence the building up of Greenleaf's 'girlfriend' Marge in the two films and introduction of Tom's unwitting nemesis, Meredith (Cate Blanchett), in Minghella's. 
Highsmith's biographer, Andrew Wilson, notes the way film-makers wrestle with Ripley's elusive sexual identity and notes Highsmith's general denial that Ripley is gay. Thus, although she did admit that he's 'a little bit homosexual', she also thought that 'he must never be quite queer' (Wilson 2003: 391; 192). ${ }^{6}$ Wilson quotes from Neil Gordon, who met Highsmith in 1992:

[...] the same psychotic split that allows Ripley to kill so easily is clearly articulated by Highsmith as the same necessary adaptation that allowed him to exist in the horrendous homophobia of '50s America. Just as Ripley denies [...] the unbearable reality of his homosexuality, he denies the fact of being guilty of murder [...] a very similar psychotic split [exists] in Highsmith herself, where she in effect denied the central thematics of her own work. (Wilson 2003: 453) ${ }^{7}$

Thus while many assume that Ripley's homosexuality has been 'filtered out' en route to the screen - particularly in Plein soleil, Village Voice considering it to have 'tactfully softened Highsmith's profane vision' - it was often only present in the original novels on the oblique level of innuendo in Highsmith's narrative, writing as she was in a relatively repressive era in which she wished to remain guarded about her own sexuality (Brown 1996: 71).

The opening line of the first novel is a good example: 'Tom glanced behind him and saw the man coming out of the Green Cage, heading his way' (Highsmith 1999a: 5). It is an ambiguous introduction to the character and the relationship between the two men leaving the bar is unclear, and shortly Tom wonders if he is a 'pervert', seeking to define his interest in him 'as if the word could protect him' and he would be able to deal with it (Highsmith 1999a: 6). It is appropriate that the other man is little more than a shadow on his peripheral vision and the act of looking over his shoulder implies a guilty past. The name of the bar implies not only the green of money and the siren dangers of wealth, but perhaps the fin-de-siècle hues of 
absinthe, the 'Green Fairy', and Oscar Wilde's green carnation, for Ripley mentions its name to Dickie, looking for a 'sign of recognition' on his face as the bar was well known, and we later hear that many of the people he knows in the city were 'queer' (Highsmith 1999a: 50; 71). These are nothing more than inferences, but the novel gives us little more than circumstantial evidence for Ripley's sexuality; we merely catch fleeting glimpses of a compromising situation or hear what others think of him and he, like Highsmith, denies it. Thus his Aunt Dottie thinks that he's 'a sissy ... just like his father', and later Dickie says, after catching Tom mimicking him in front of a mirror: "'I'm not queer. I don't know if you have the idea that I am or not." "Queer?" Tom smiled faintly. "I never thought you were queer"' (Highsmith 1999a: 34; 70). Ripley denies that he is either, but Highsmith's narrator, closely aligned with its protagonist, never addresses whether he actually is gay or not.

Marvellous juxtapositions occur around the queer subject, including a passage in which Tom and Dickie come across a group of men performing acrobatics in swimming trunks on an embankment in Cannes. Tom is transfixed, observing that they all wear the 'same yellow G-strings' and one of the men smiles at him, while Dickie becomes sour and walks off. 'You'd think he'd never seen a pansy!' Tom mutters to himself (Highsmith 1999a: 86). In subsequent books Ripley's marriage to Heloise is a sexual one, yet their fond if not passionate relations appear contrived and her equally cultured tastes suggest a relationship maintained for financial security and social-column ornamentation; and appearances matter to Ripley, especially as an ironic mask for his underworld activities. Highsmith facilitates questions about Ripley, but makes sure that his desires remain unnamed and without label. But this does keep readers guessing and perhaps reading more into the crumbs of innuendo than they would otherwise. ${ }^{8}$ As Robert Aldrich notes of the charged iconographic use of the Mediterranean by homosexual artists, while these texts and contexts may signal 'special meaning for those who empathise most directly with their characters or situations', they remain 'accessible to all publics' (Aldrich 1995: 8). 
Indeed, the 'relentlessly beautiful' landscapes that Ripley inhabits in the films both frame and disavow the homoerotic, which registers upon it as oblique shadows; appropriate enough for a character whose French home in the novels is called 'Belle Ombre' or 'Beautiful Shadow'. As Robert Aldrich has illustrated, the Mediterranean has a long tradition of being visited by those seeking to touch a culture that might, through history, myth and an iconography spanning the classical to the present day, legitimate sexual possibilities prohibited elsewhere (Aldrich 1995). Thus, many of the locations frequented by Tom and Dickie in the texts are associated with the homoerotics produced by artists such as Wilhelm von Gloeden and Wilhelm von Plüschow, who worked along the coasts where both films were shot. If the aesthetics of landscape connote a certain homoerotic charge, this amplifies what we might perceive within the periphery of the frame, juxtapositions and glimpses of possibilities that dissolve when gazed at directly. Even Plein soleil, which is most guarded about its subtext, contains glimpses of what look like male couples in the background, echoing Highsmith's ploy of placing 'queer' elements in close proximity to her subjects without directly 'contaminating' them. Painting straight from a queer palette, if you will. This perhaps extends to the Italian artistic landscape too. Peter in $T M R$, for example, observes a certain repressed homoerotic presence in his comment that: 'officially there are no Italian homosexuals ... [which] makes Michelangelo and Leonardo very inconvenient'.

We might then forgive these texts for privileging surface appearances and thus having to bear the critical stigmata of 'gloss' for as I noted earlier, appearances are everything. As Thomas Mann has observed, there is a strong aesthetic rhyme between Nietzsche's famous remark that 'the existence of the world is justified only as an aesthetic phenomenon' (which gives Clément's film an 'ugly' political edge to its beauty, as Darke notes) and the remark by another late nineteenth-century iconoclast, Oscar Wilde, that: 'it is only shallow people who do not judge by appearances' (Nietzsche 1993: 8; Darke 1997; Mann 1969: 169). There is a link here between Nietzsche's dynamic of Apolline surface beauty with half-obscured 
Dionysiac significance, which I will address shortly when I consider the films' stars, and the camp sensibility that Wilde announces, where performance and image can be deployed not only in the pursuit of refinement but obliquely to articulate sexual identity too. Likewise, in book and film, Ripley is keen to fashion what he perceives to be an aesthetic sensibility, defining himself with and against Dickie, often through costume, in order to lose what he sees as American brashness and become the European gentleman abroad. Early in the book, Ripley becomes self-conscious of the art of posing as he cruises towards Italy, thinking of his aunt he writhes in a deck-chair, 'but he writhed elegantly, adjusting the crease of his trousers'; and later in the novel, as he fashions his new identity in Venice, he furnishes himself with that ultimate emblem of decadence, the silk dressing gown (Highsmith 1999a: 35; 185). Ripley's tastes are symbiotic with his sexual proclivities. The abject distaste he expresses for the curtains in his Roman apartment is immediately echoed in the way he 'disliked even touching' Marge's letters and is later 'repelled' at the thought of her draping her bras over his chairs at night or spilling wine over his 'beautiful' table (Highsmith 1999a: 117; 119; 195). Given such cross-sensitization of setting, appearance and sexuality, I will now move closer to the film texts and examine the relationship between the stars who have embodied Ripley, beginning with Ripley's first sighting of Dickie and a singular pair of bathing trunks.

\section{Rippling talent: beautiful nightmares and the six-pack fallacy}

While Highsmith's book contains some detail about Ripley's life in New York before leaving for Italy, the two films' narratives have different starting points in; TMR cuts this background down to an extended title sequence, while Plein soleil omits it entirely, plunging the viewer directly into a Roman café well into the men's relationship. What Clément's film loses by doing this is the revealing first meeting of Ripley with Dickie.

In the novel, the men meet on Mongibello's beach itself, but in Minghella's film Dickie and Marge (Gwyneth Paltrow) are first seen in a telescopic long-shot framed within 
the vignette of Ripley's binoculars, through which he gazes from his hotel room as he practises his Italian. Dickie is poised on the deck of his boat like a statue, the sun backlighting his blonde hair as he and Marge jump into the bay. The flattening effect of the perspective and background of sparkling blue water gives the images an ethereal, unreal effect, demonstrating the director's stated desire to surrender the film's viewpoint to Ripley's obsession 'for image and surface and beauty'. We then see Law and Paltrow rising out of the sea, Dickie's head turned aside to present his confident profile. This pose, combined with the saturated golden tones of his body, designates the 'two gods wading out of the water' described by Minghella, as progressively closer shots literally focus Ripley's objectification of Dickie; he repeats the Italian for 'this is my face' as he looks at him, foreshadowing events to come. ${ }^{9}$ If Dickie is established as a radiant figure from classical mythology, effectively emerging from the imaginative firmament of Ripley's mind, then their actual meeting on the beach as the sequence progresses sets up a number of incongruities that run through the film.

In this scene, Ripley walks down the crowded beach, carrying his shoes, and strikes up a conversation with the couple on the beach on the pretence that he knew Dickie at Princeton. Dickie is once more part of the landscape as he languishes on a deckchair with his arms folded confidently behind his head. He appears as a continuation of the sea and sun from which he emerged, the novel describing his 'lean brown feet planted in the hot sand', unlike Ripley, who remains highly uncomfortable with the heat (Highsmith 1999a: 41). Minghella shares Highsmith's desire to project Ripley's discomfort with this environment through the contrast in the men's bodies, which he makes immediately apparent through what he describes as the 'alabaster body of Ripley's against the Mediterranean'. The bronzed Dickie is certainly swift to comment on the tonal disparity between Ripley and himself as he exclaims 'you're so white [...] grey, actually'. Tom is clearly not part of Dickie's leisured class of Americans abroad but his remark also suggests that there's a deathly - Highsmith describes him as 'ghost-white' - and slightly tainted quality to Ripley's grey-white body (Highsmith 
1999a: 40). Greenleaf even implies that there's something feminine about it as he compares the other man's colouring to that of Marge, in the tradition of thought that deems that women should be pale and interesting and so very much part of the domestic/sexual indoor environment; thus already underscoring their meeting with ambivalent sexual undercurrents.

Costume is crucial here, as Matt Damon is dressed in an almost fluorescent pair of yellow-green woollen swimming trunks that contrast with the more subtle and expensivelooking patterned shorts worn by Dickie. Combined with his paleness, Ripley's otherness as well as his awkwardness is made explicit; he's just not comfortable with being so physically exposed. ${ }^{10}$ This is made clear as he defends his colour by saying that's it's just an 'undercoat [...] you know, primer', a blank canvas that he hopes to remodel in either Dickie's form or a shape that pleases him. As it is, he lacks Dickie's socially polished performance, as if his greyness expresses the dissonance and ambiguity of his desires; that he lacks surface integrity. The bright green of his trunks makes him appear ridiculous but also, emphasized by the composition of the shot, draws attention to his waist and perhaps the incongruity of his possible sexual interest in Dickie. In the novel this aspect is much more explicit as Highsmith repeatedly comments on how he wears 'a black-and-yellow thing hardly bigger than a Gstring' (recalling the G-stringed 'pansy') and that it was 'very revealing' (Highsmith 1999a: 40-1). The film's change in emphasis might actually be to downplay the physical attributes of Damon, who after all is a Hollywood pin-up, a fact that threatens to upset the requirement for Dickie to be the object of the gaze for the scene to make sense. Moreover, although Damon appears pale and none of the other men on the beach wear anything like his chromaticallychallenged and unflattering costume, they also lack his conspicuously well-toned torso, which stands out like a beacon in the first wide-shot of him walking down the beach. There is a real conflict here: Damon boasts the most taut six-pack on the beach, yet how and why did Ripley, the man of the shadows, attain such a svelte physique in 1950s America? 
This is the question Peter Bradshaw poses as the 'six-pack fallacy' in his review in

\section{The Guardian:}

There is only one big error: on the beach, Matt Damon is shown sporting a crisp set of abs, decades before these were invented. (It is part of what I have elsewhere identified as the Six-Pack Fallacy, whereby any remotely presentable male lead must always have the Pack, but is not shown doing the thousands of daily abcrunches needed for its upkeep.) (Bradshaw 2000).

Adam Mars-Jones concurs in The Times, noting Ripley's: 'film star's trophy hard body of the 1990s, but never mind' (Mars-Jones 2000: 45). Certainly, contemporary Hollywood aesthetics demand male leads to possess a six-pack, a form of 'body fascism' it shares with the music and advertising industries and also the gay scene. ${ }^{11}$ The Times also reported that Damon lost $201 \mathrm{bs}$ in weight in order to play the part, which would have revealed rather than hidden his abs, if anything (Cliff 2000: 42). Shortly before the film's release the press speculated about whether Damon was the right actor to play Ripley, the Guardian referring to him as the 'chunky, slimy Matt Damon', presumably referring to his muscularity rather than weight, while the Independent Review was initially concerned that he was 'too pleasingly formed' to carry it off (Cox 1999: 9; Clarke 2000: 12). And it is true that the actor's reception up until TMR portrayed him as an all-American golden boy through his association with Good Will Hunting (Gus van Sant, 1997), for which he and co-writer Ben Affleck received an Oscar. 'He's every woman's fantasy', claimed an Evening Standard headline in 1998, while The Guardian spelt out his appeal: 'Appearance: Modern Hollywood incarnate, all pearly whites and pubescent appeal; your mum wants to bake him apple pie, your wee sister wants to make him an indecent proposal' (Iley 1998: 21; 'Pass Notes' 1997: 3). Indeed, 'our knowing so much about Damon interferes with his art', Quentin Curtis adds, suggesting that the 
'profoundly together, rounded young man' of media profiles prevents viewers from fully accepting the darker sides of his performance (Curtis 1998: 17). In short he seemed more ' $\mathrm{Mr}$ Nice Guy’ than Mr Ripley (Daly 1998: 68).

While many reviews offer comments along the lines of 'not just a pretty face' in recognition of his acting and screenwriting abilities, certain ambiguities in Damon's public persona were apparent in 1998 that were conducive to his playing Ripley ('Pass Notes' 1997: 3). The Evening Standard eloquently calls him a 'beautiful nightmare' in one piece (one recalls 'Belle Ombre' at this point), because of the fact that he's not quite the 'boy next door real dream' that he first appears but possesses a 'catalogue of imperfections' that keep one interested if not always in terms of sexual fantasy, that he's 'clever' and 'beautiful' but that 'you want to surrender to him and save him at the same time' (Cox 1998: 21). If, then, he is a beautiful nightmare with human imperfections, that constructs him as the ideal Ripley in relation to the 'impossibly beautiful' Law as Dickie, a relationship that he propagated while promoting the film (DT 2000). Adopting the language of confession and admission when talking about his co-star, Damon thus 'openly admitted' to the Evening Standard 'a grudging envy for his set-up. "Not only does he look as if he's sculpted from marble, he's a great actor with this wonderful family life" (Pearce 2001: 3). A few months later in The Times he 'confessed to a touch of art-imitating-life jealousy of Law [...] "he was travelling and having fun, while I was living with the thoughts and manners of Tom Ripley' (Potton 2001: 9). As Minghella puts it, 'there aren't many people in the world who can make Matt Damon feel insecure and plain'. ${ }^{12}$ The Independent Review even tried to compare Ripley's love for Dickie with the alleged sexual relationship between Damon and actor Ben Affleck. After offering that Affleck is 'very much a Dickie Greenleaf in his own way, in that he's so charismatic', the interviewer swiftly asks if that makes him Ripley: 'Damon looks horrified. "No," he grins nervously, visibly backing off' (Clarke 2000: 13). However, such extra-diegetic rumours do provide the kind of engine of innuendo that complements a text like TMR so well. 
Impossibly beautiful is a fine definition of Law's looks, for they possess that slightly unreal or too-good-to-be-true quality - unlike the flaws noted of Damon, Sean Macaulay suggested that Law's face is like 'a computer composite of good-looking features, strangely mixing hard and soft' - that inspires endless references to classical sculpture while also arousing suspicion that something less palatable must lie behind; similarly, Minghella once called him “"unbearably handsome”" (Segal 2002: 21; Macaulay 2001: 16). While contextual discourses situate him as unambiguously heterosexual, he has played more than his share of gay parts, including that of Oscar's lover 'Bosie' in Wilde (Brian Gilbert, 1997). The elusiveness of his sexual, and indeed class, appeal made him an ideal siren for both Ripley and Marge, as Minghella puts it: 'who else would you rather be than Jude Law?'. ${ }^{3}$ Alain Delon, perhaps?

\section{The Delon affair}

Just as many have noted the incongruity of Dorothy's yearning for the sepia Kansas over a Technicolor Oz, Plein soleil's problem is that why would you want to be the rather ordinary Philippe Greenleaf (Maurice Ronet) when you could be Alain Delon? Ronet's charms seem entirely downplayed in the company of Delon, even in the first scene. Although Philippe is evidently rich and comfortable in the café at which they are introduced, the heavy, tancoloured shirt that he wears unbuttoned to reveal an un-aspirational physique lends him a comparatively shabby air that with his over-tanned and perspiring complexion make him look more like an aged Tony Curtis than the projected fantasy of the man sitting next to him. In contrast, Ripley sits upright and alert, is well-groomed and wears a pale blue shirt to match his eyes so as to make the most of the film's Eastmancolor palette. But then, perhaps, this is a film more about Ripley than Greenleaf, the homoerotic subtext ostensibly displaced into a story of heterosexual envy - Ripley clearly desiring the dusky, guitar-strumming Marge - and the gay innuendo left for the landscape discussed earlier and a strange moment that occurs 
during the twenty-five-minute sailing sequence that culminates in Philippe's death. There, out of the blue, Philippe fixes his eyes on Ripley and says 'I love Marge'. This could just be a defence against Ripley's undermining of their relationship, but there is an intensity and stillness to the men's looks that leaves meaning undetermined and therefore quite powerful. The same is true of the scene in TMR when Ripley asks if he can get in the bath with Dickie as they play an over-determined game of chess together, resulting in an awkward, lingering moment as the two men make eye contact. Although Minghella expresses surprise when accused of having intensified the novel's 'homoerotic landscape', he acknowledges that the bath scene is the most 'thinly disguised' in the film and observes the cinematic phenomenon that 'the screen shouts whenever there's a look between two men' ${ }^{14}$ As Charlotte O'Sullivan suggests, this is 'a film about a look that cannot speak its name' (O'Sullivan 2000: 53).

These are exactly the kind of ambiguous looks between men that mainstream cinema usually tries to avoid. This is the kind of male gaze explored in the work of Richard Dyer, Yvonne Tasker and Steve Neale, where any objectification of the male body, whether or not motivated by the gaze of other characters, becomes tacitly homoerotic due to cinema's allegedly male gaze; thus Tasker's discussion of action cinema's disavowal of the sexual gaze through violence, or the kind of hysterical fetishization and fragmentation of the body described by Neale (see Dyer 1992; Neale 1992; Tasker 1993). Hence the visual obsession with Delon's beauty, the shots of what Guy Austin calls his 'mask-like face', his repeated shirtlessness and the way his still moments are swiftly supplanted by restlessness and athleticism, which Darke terms 'a closely choreographed ballet of dissimulating gestures and movements' (Austin 2003: 62; Darke 1997). Like the ambivalent facade of Law, Delon's image is an unquiet presence, returning us to the heightened 'gloss' of the film that has elicited comment such as the Monthly Film Bulletin's 1961 attack on the way Clément had been bewitched by the Nouvelle Vague style, but only for its 'surface effects'. Thus 'we are 
continually being invited to look at objects which are neither assimilated into the narrative nor made telling or revealing on their own account' (P.H. 1961: 94).

This clearly applies to Delon too and, as Ginette Vincendeau has observed, his early films are 'structured around the narcissistic display of his face and body' (Vincendeau 2000: 174). Delon has often, like Law, been described as a Narcissus figure, the Sunday Times arguing in 1964 that 'a simple, unaffected narcissism informs his whole personality', a concept beautifully illustrated by the scene in which he kisses his own reflection while impersonating Philippe in Plein soleil (ST 1964: 25). While Vincendeau argues that explicit erotic display is accommodated successfully in Delon's early films, the MFB's comment about unassimilated objects indicates that there is some disparity between image and narrative in the film, although it is certainly true that Ripley's character is so disruptive of himself in terms of identity and appearance that any cognitive friction is entirely in the film's interest. For example, in the sequence where he becomes a flâneur, wandering aimlessly through a fish market in Naples, smiling at the sellers as the camera incongruously dwells on fish heads on the floor. However, all the flânerie is really done by the spectator, not Delon; the film cuts back and forth from close-ups of him and mid-shots of him gazing at and touching objects, complete with the discontinuity editing, hand-held photography and lens flare that we would expect from the New Wave. Even passers-by in the background are drawn to stare at Delon. It is a moment of self-reflexive rupture that never occurs with Damon, who is perhaps immersed more entirely within the role, despite that yellow-trunked moment.

Peter Bradshaw was wrong, of course, when he suggested that abdominal muscles were a recent invention, for one only has to look back to the ubiquitous publicity shots of a shirtless Alain Delon's Ripley at the wheel of Philippe's boat in Plein soleil to behold one of cinema's most iconic six-packs. Not that he was the only one: his contemporary Jean-Paul Belmondo boasted a rival physique, although Delon always felt slightly excluded or too 'foreign', as he once claimed, for French cinema, indicating perhaps that his looks and 
persona granted him a more international identity (Mann 1971). These physiques might suggest that French cinema was decades 'ahead' of Hollywood fashions - Vincendeau noting that the 'slim and toned' Delon and Belmondo 'connoted the modern Frenchman' on holiday in fashionable coastal towns - at a time when barrel-chested brawn and slightly older stars still generally reigned supreme, hence Delon appearing surprisingly 'modern' to contemporary audiences (Vincendeau 2000: 167). Critics thus seemed to articulate a kind of 'shock of the old' when reassessing the film for its 1997 re-release, indicating a heightened interest in the actor's body. The sight of a young Delon 'languishing shirtless' is the 'textbook definition of cool', thought the Independent, and 'alone warrant[s] the price of admission'; 'watch him and weep' enthused Anne Billson; while Matthew Sweet helpfully advised his readers to 'stick a photo of him on your biscuit tin and you'll never pig out again' (Gilbey 1997: 7; Billson 1997: 10; Sweet 1997: 11).

Within the world of the film, such surface excesses are entirely consistent: the film even begins, after a shot of sea-planes arriving, with a montage of garishly coloured 'postcards' of Rome which eventually segue into the hand of Ripley scrawling on a postcard. It approaches the Mediterranean with the travellers' appetite to consume visually, to drink off the sunny sheen of the landscape, reinvent themselves and indulge hedonistically in more sequestered pleasures. Delon possesses as much Apolline charisma as Law, albeit of a more athletic variety, and both stars were promoted with the kind of Apolline/Dionysiac split Nietzsche posits in The Birth of Tragedy. While I have explored this in more detail elsewhere (see Williams 2003), the relevant aspect of Nietzsche's argument is that, in ancient Greek culture, Apollo, the sculptural god of art and light, is artistically combined with Dionysus, the god of indulgence who is sexual, dissonant and broken. By looking on Apollo's translucent, mask-like countenance, the traumatic horrors of the world were made bearable by being tamed but not obscured (Nietzsche 1993). 
This binary of beauty and horror, which can also be read in terms of the hidden criminality and indeed (homo/bi)sexuality of Ripley is echoed in the publicity that surrounds Delon and Plein soleil, starting with the English-language publicity poster illustrated in the press-book, which described him as an 'angel-faced monster', possessing: 'the face of an angel - the heart of a devil!'. ${ }^{15}$ The Daily Mail even suggested in 1965 that 'his personality was tempered and steeled' by the war in Indochina, a reference to his well-known military service. This war connection adds greatly to the Nietzschean binary suggested above, especially as Delon is quoted as saying when describing his appearance: "'this face is a pure face [...] It is a young face [...] but it is not me. Inside I am tortured"' (Levin 1965). Much like the tributes to the series of 'broken beauties' played by Law, 'men whose physical attributes offer no guarantee against psychological damage' - quite the contrary (Brown 1998: 54). Moreover, in $T M R$, the point at which the hidden subtext of Ripley's interest in Dickie becomes explicit, during the argument on the boat that precipitates the latter's murder, is also the point at which Law's features are rendered as shocking and Dionysiac, as a sudden closeup of his angry, bloody face bears down on Ripley; prosthetics distorting and breaking the integrity of his surface. Meanwhile, Time magazine provides a wonderful description of Plein soleil, suggesting that the way Henri Decaë bathes the film in 'innocent holiday light' makes Ripley's actions more 'hideous by contrast, like a big hairy spider crawling slowly across a travel poster' (Time 1961). Thus even more than Law, Delon is 'impossibly beautiful' or 'absurdly handsome', his luminous, 'deliciously incongruous' features constantly alluding to something unseen lurking just underneath the surface (Billsun 1997: 10; Perry 1997: 7; Powell 1961). As Vincendeau concludes, it is Delon's 'beauty itself, in its excess, which is cruel' (Vincendeau 2000: 176).

Since 1960, the construction of Delon's persona has taken on an even more Ripleyesque aspect through a series of events known as the Markovic affair but which has also been referred to in headlines as 'the Delon affair' (Fox 1969). It all started with reports 
about the death in 1968 of Stefan Markovic, the actor's friend and stand-in, amid suspicious circumstances. The story continued through 1969 and into the 1970s, accumulating allegations about drugs and also politics through tangled connections with Pompidou and never seems to have been resolved. Meanwhile Delon's apparent associations with the demimonde came further out into the open. As the Sunday Times put it, Delon was now 'the star of a living scenario where the exotic tastes of Paris society and the literally murderous milieu of underworlds and gangsters had come to an explosive embrace' (Fox 1969). The press also entwined its reporting with speculation about Delon's sexuality and talk of blackmail, suggesting that there were photographs proving 'his homosexual affair' (Webster 1975). However, Delon remained refreshingly candid about such questioning. When asked by the BBC in 1969 whether he had 'homosexual tastes' Delon simply replied "'So what's wrong if I had, or if I did - would I be guilty of something? If I like it, I do it"” (Todd 1969).

Given the vague, 'guilty of something' elements of crime, sexuality and even the body double, it is surprising that more hasn't been made of the connection between the Dionysiac Delon/Ripley/Greenleaf personae. Reading the Sunday Express's description of the actor in 1971 the similarity is striking: 'Rich, notorious, successful, sexy and intelligent - that is Delon. A man whose striking physical appearance is tinged with the aura of scandal' (Mann 1971). Whatever the truth behind these stories, it certainly keeps recurring to haunt him for better or worse, much, indeed, like the 'Murchison Affair' in the Ripley books, where Ripley's connection with the disappearance of an art connoisseur (whom he murdered) is alluded to by the media whenever his name is mentioned. Alexander Walker could thus write in 1997 that Plein soleil 'has gained a baleful resonance it didn't have' in 1961, namely that 'Delon's subsequent off-screen career $[\ldots]$ touched the real criminal worlds that Tom Ripley might have felt at home in' (Walker 1997: 17). The film has thus effectively been intertextually rewritten through a process of acculturation and retrospective irony. 


\section{Conclusion}

In many ways the Ripley films are texts about stardom as much as murder, about obsessive desire and over-identification with a distant, fantastical object. At the end of Plein soleil, Ripley is taken away by the police and we are left with a wide shot of an Italian beach, complete with a line of parasols, a small island in the sea and a boat sailing in the bay, all reminders of the beauty and horrors that have come before. Absent is Alain Delon, who has been present throughout the film, leaving us with little more than one of the Mediterranean postcards with which the film began. Likewise, the final image of Minghella's film finds Ripley becoming kaleidoscopically enveloped and then obscured in darkness as the mirrored doors of his cabin swing and close around him. Although Damon's Ripley is ostensibly imprisoned by his myriad reflections at the film's end, the enigmatic 'Lullaby for Cain' that bookends the film, brings a sense of cyclical disquiet to the close. The swinging doors are a visual quote from Clément's film, and the scene in which a bare-chested Ripley lies in his hotel bed, hoping that the detective who questions him will not notice the incriminating items of clothing revealed by an opening, mirrored wardrobe door on the margin of the frame. In that film the door is pushed shut by an oblivious detective, closing the closet door on the queerness of Ripley (his relationship to Philippe) and leaving him to pursue Marge. After forty years the shifts in Delon's persona have allowed subsequent audiences to open those doors once more. These are texts that remake, fold in on themselves and return us to the beginning, drawing in shards of peripheral innuendo through the sheer force of attractiveness to their beautiful, broken centres.

\section{Notes}

Thanks to David Cobbett and Thomas Ribbits for their conversation on Ripley.

1 There have been other Ripleys on the screen. Wim Wenders made The American Friend in 1977, starring an unlikely Dennis Hopper as Ripley, a casting decision to which Highsmith 
objected, Wenders relates, 'almost physically' (Wilson 2003: 361). Wilson quotes from a letter from Wenders to himself, 22 February 2002. Wenders's film was based on Ripley's Game, which was recently made into an intriguing version by Liliana Cavani (2002), with John Malkovich in the title role. A film by Roger Spottiswoode based on Ripley under Ground is also in production.

2 These were published between 1970 and 1991, namely: Ripley Under Ground, Ripley's Game, The Boy Who Followed Ripley and Ripley Under Water.

3 This is particularly true in the move from the first to the second novel, where readers might be surprised to learn that Ripley, once the queerest of characters, is now ostensibly living as a happily married heterosexual in what resembles a 'little castle' on the outskirts of Paris (Highsmith 1999b: 11).

4 Yet, even more than TMR, Plein soleil does present many apparently 'Hitchcockian' moments, not least in the staircase sequence that frames Ripley's murder of Greenleaf's prying friend Freddy. However, such references are to the Expressionistic vocabulary that Hitchcock borrowed from Europe in the 1920s, and perhaps the figure of Hitchcock is mainly evoked because he shares, or indeed appropriates, Highsmith's interest in juxtaposing murder with the domestic and pricking public facades in order to expose the ambiguously 'deviant'.

5 While these observations are rather unfair, a dubbed English-language version (bizarrely titled Purple Noon) was distributed in the UK and US six months after the initial release, although it still managed to disturb The Spectator with its portrayal of an Italy 'where Italians talk accentless and fluent American' (Quigley 1962).

6 Wilson quotes from 'Patricia Highsmith: a gift for murder', The South Bank Show, LWT, 14 November 1982; Patricia Highsmith’s diary, Cahier 23, 28 March 1954.

7 Wilson quotes from a letter from Neil Gordon to himself, 9 November 2001.

8 Persistent insinuations about his sexuality first explode into the foreground as Ripley attends a gay bar called the 'Glad Ass' in Berlin during The Boy Who Followed Ripley, a 
sequence that reads like a vulgar explosion of sexuality after so much repression, heralding the arrival of the 1980s. Even if the 1950s are a long way away (though like Dorian Gray, Ripley doesn't seem to age), all is never as it seems and Ripley's relationship with the eponymous boy remains strictly platonic (Highsmith 2001: 122).

9 Quotes from Minghella (2001) unless indicated otherwise.

10 Damon relates how costume designer Ann Roth instructed Jude Law not to wear underwear under his clothes to make them "'hang better", but said to him "“Of course, Tom wears underwear. It would be too exposing of himself not to"” (Lemon 2000: 42).

11 One British website decries the '6 pack fallacy', telling its visitors to 'burn your jockstrap'. See 'The 6 pack fallacy', www.dollsoup.co.uk/burn/object.htm.

12 'Reflections on The Talented Mr Ripley' (Minghella 2001).

13 'Making the soundtrack' (Minghella 2001).

14 Minghella (2001).

15 Plein soleil English-language press-book, BFI library, London.

\section{Works cited}

Aldrich, Robert (1995) The Seduction of the Mediterranean: Writing, Art and Homosexual Fantasy (London: Routledge).

Alpert, Hollis (1961) The Saturday Review (23 September) (untitled, unpaginated review).

Austin, Guy (2003) 'Macho men: Jean-Paul Belmondo and Alain Delon', in Guy Austin, Stars in Modern French Film (London: Arnold), 47-62.

Billsun, Anne (1997) 'Impossibly beautiful Alain Delon', Sunday Telegraph Review (24 August), 10.

Bradshaw, Peter (2000) 'The Talented Mr Ripley', The Guardian (25 February), www.film.guardian.co.uk/News_Story/Critic_Review/Guardian_review/0,4267,14027 4,00. html (accessed 31 July 2003). 
Brown, Georgia (1996) Village Voice (2 July), 71 (untitled clipping).

Brown, Paul (1998) 'Law and disorder', Sunday Times Magazine (19 April), 52-6.

Clarke, Roger (2000) 'Ripley: my part in his downfall', Independent Review (18 February), $12-13$

Cliff, Nigel (2000) ‘An Englishman abroad again', The Times (14 February), 42.

Cox, Tom (1999) 'Will the real Mr Ripley please step forward', The Guardian (9 April), 8-9.

Curtis, Quentin (1998) 'The making of a star', Daily Telegraph (19 January), 17.

Daly, Steven (1998) 'Mr Nice Guy', Daily Telegraph (Weekend Supplement) (14 November), 68.

Darke, Chris (1997) 'Inaction Man’, Independent (Long Weekend) (23 August).

DT (2000) 'In the style of: Jude Law', Daily Telegraph Magazine (28 October) (unattributed cutting, BFI library).

Dyer, Richard (1992) 'Don't look now: the male pin-up', in The Sexual Subject: A Screen Reader in Sexuality, ed. Screen (London and New York: Routledge), 265-76.

Fox, James (1969) 'The Delon affair', Sunday Times Magazine (11 May) (unpaginated clipping, BFI library).

Gilbey, Ryan (1997) Independent (Tabloid) (21 August), 7.

Highsmith, Patricia (1993) [1991] Ripley Under Water (London: Vintage Crime/Black Lizard).

(1999a) [1955] The Talented Mr Ripley (London: Vintage).

(1999b) [1970] Ripley Under Ground (London: Vintage).

(1999c) [1974] Ripley's Game (London: Vintage).

(2001) [1980] The Boy Who Followed Ripley (London: Vintage).

Hill, Derick (1961) Financial Times (2 June) (unpaginated review).

Iley, Chrissy (1998) ‘He’s every woman’s fantasy', Evening Standard (2 February), 21.

James, Nick (2000) 'My bloody valentine', Sight and Sound 10.2 (February), 14-17. 
Lemon, Brendan (2000) 'The talented Mr Damon', Attitude (March), 36-42.

Levin, David (1965) 'The girls who lost Alain Delon to the world's women', Daily Mail (2 September) (unpaginated cutting, BFI library).

Macaulay, Sean (2001) 'Here's looking at you, kid', The Times (29 September), 16-17.

Mann, Roderick (1971) Sunday Express (14 November) (unpaginated cutting, BFI library).

Mann, Thomas (1969) 'Wilde and Nietzsche', in Oscar Wilde: A Collection of Critical Essays ed. Richard Ellmann (Englewood Cliffs, New Jersey: Prentice-Hall), 169-71.

Mars-Jones, Adam (2000) The Times (24 February), 45 (untitled cutting, BFI library).

Minghella, Anthony (2001) The Talented Mr Ripley, director's DVD commentary (Warner Home Video).

Neale, Steve (1992) 'Masculinity as spectacle', in The Sexual Subject: A Screen Reader in Sexuality, ed. Screen (London and New York: Routledge), 277-87.

Nietzsche, Friedrich (1993) [1872] The Birth of Tragedy, trans. S. Whiteside (London: Penguin).

O’Sullivan, Charlotte (2000) 'The Talented Mr Ripley', Sight and Sound 10.3 (March), 53-4.

'Pass Notes' (1997) 'Pass Notes: Matt Damon', The Guardian (Section 2) (22 December), 3 (unattributed cutting, BFI library).

P. H. (1961) 'Plein soleil', Monthly Film Bulletin. 28. 330 (July), 94-5.

Pearce, Gareth (2001) 'Natural Law’, Evening Standard (Hot Tickets) (8 March), 3.

Perry, George (1997) Sunday Times (24 August), 7 (untitled cutting).

Potton, Ed (2001) 'The wanderer', The Times (Play) (20 May), 9.

Powell, Dilys (1961) Sunday Telegraph (4 June) (unpaginated clipping, BFI library).

Quigley, Isobel (1962) The Spectator (19 January) (unpaginated review).

Segal, Victoria (2002) 'Uncommon Law’, The Times (Play) (16 March), 21.

ST (1964), Sunday Times (Colour Supplement) (15 November), 25 (unattributed review).

Stimpson, Mansel (1997) 'Plein soleil', Gay Times (September), 93. 
Sweet, Matthew (1997) Independent on Sunday (24 August), 11.

Tasker, Yvonne (1993) Spectacular Bodies: Gender, Genre and the Action Cinema (London: Routledge).

Time (1961) ‘Messy Ménages', Time (18 August) (unattributed review, BFI library).

Times (1961) The Times (2 June) (unattributed review, BFI library).

Todd, Oliver (1969) 'The Markovic affair: the French film star Alain Delon talks to Oliver Todd', The Listener (27 March) (transcript of BBC1's 24 Hours programme).

Vincendeau, Ginette (2000) 'Jean-Paul Belmondo and Alain Delon: one smiles, the other doesn't', in Ginette Vincendeau, Stars and Stardom in French Cinema (London: Continuum), 158-95.

Walker, Alexander (1997) 'Plein soleil', Evening Standard (Hot Tickets) (21 August), 17.

Walter, Natasha (2003) 'A lover, not a killer’, Guardian (Review) (12 July), 13.

Webster, Paul (1975) 'The deadly affair', The Guardian (15 September) (unpaginated clipping, BFI library).

Williams, Michael (2003) Ivor Novello: Screen Idol (London: BFI).

Wilson, Andrew (2003) Beautiful Shadow: A Life of Patricia Highsmith (London: Bloomsbury).

\section{Films}

Cavani, Liliana (2002) Ripley’s Game (US/UK/Italy).

Clément, René (1960) Plein soleil (France /Italy).

Gilbert, Brian (1997) Wilde (UK/Germany/Japan).

Hitchcock, Alfred (1951) Strangers on a Train (US).

Minghella, Anthony (1999) The Talented Mr Ripley (US).

Sant, Gus van (1997) Good Will Hunting (US). 
Wenders, Wim (1977) The American Friend [Der Amerikanische Freund] (West Germany/France). 